\title{
KONSEP PENATAAN PERMUKIMAN TEPIAN SUNGAI DURI ROXY JAKARTA BARAT
}

\section{Naniek Widayati Priyomarsono ${ }^{1}$, Fermanto Lianto ${ }^{2}$, Friska, Mariana, dan William ${ }^{3}$}

\author{
${ }^{1}$ Prodi Magister Arsitektur, Universitas Tarumanagara Jakarta \\ Email: naniekw@ft.untar.ac.id \\ ${ }^{2}$ Jurusan Arsitektur dan Perencanaan, Universitas Tarumanagara Jakarta \\ Email: fermantol@ft.untar.ac.id \\ ${ }^{3}$ Prodi Magister Arsitektur, Universitas Tarumanagara Jakarta \\ Email: naniekw@ft.untar.ac.id
}

\begin{abstract}
The rapid development of Jakarta city is sometimes uncontrollable and independent of supervision. Likewise, a series of villages on the banks of the Duri river opposite Roxy Mas, which grow and develop without control, so it looks very vile. The residents of the village series consist of middle to lower class people, with livelihoods; motorcycle taxi drivers, construction workers, vegetable artisans, washermen, porter, and hawkers. This kind of work potential is actually needed by middle and upper class city residents. Problems that arise are the slum neighbourhood that ruin the city view, the danger of fire, the inhabitants of the community are very easily triggered by conflicts that cause quarrels. The method used is qualitative by way of approaching the inhabitants of society by using the theory of Strategy Grounded Theory Research, this is due to the fact that not only physical buildings are studied but also include people who occupy the research area and their culture. Devotion is done in 3 stages ; Stage1. a. Collecting social data by means of in-depth interviews with Focus Group Discussions (FGD), b. Unit measurement of space. c. Check the existence of the balcony above the river and the door to the outside of the unit leading to the balcony. Expected outcomes are in the form of guidelines regarding spatial planning per unit and its balconies. Stage 2; Give examples of healthy units both in terms of material selection, air circulation, color selection. Stage 3; Give examples of a sturdy balcony, beautiful, pleasing to the eye, and colorful painting. Now this is only devotion to stage 1.
\end{abstract}

Keywords: Guidelines; Series settlement; River bank.

\begin{abstract}
ABSTRAK
Perkembangan kota Jakarta yang demikian pesat kadang tidak terkendali dan terlepas dari pengawasan. Demikian juga perkampungan deret di tepian sungai Duri di seberang Roxy Mas, yang tumbuh dan berkembang tanpa kendali, sehingga terlihat sangat kumuh. Penghuni dari kampung deret terdiri dari masyarakat golongan menengah ke bawah, dengan mata pencaharian; tukang ojek, tukang bangunan, tukang sayur, tukang cuci, kuli, pedagang asongan. Potensi kerja semacam ini sebenarnya dibutuhkan oleh warga kota kelas menengah ke atas. Permasalahan yang muncul adalah perkampungan deret yang kumuh merusak pemandangan kota, bahaya kebakaran, masyarakat penghuni sangat mudah terpicu konflik yang mengakibatkan pertengkaran. Metoda yang dipakai kualitatif dengan cara pendekatan kepada masyarakat penghuni dengan memakai teori Strategy Grounded Theory Research, hal ini disebabkan karena yang diteliti tidak hanya fisik bangunan saja tetapi termasuk manusia yang menempati lahan penelitian tersebut beserta kulturnya. Pengabdian dilakukan dengan 3 tahapan yaitu; Tahapl. a. Menjaring data sosial dengan cara wawancara mendalam dengan Focus Group Discussion (FGD), b. Pengukuran unit ruang. c. Pengecekan keberadaan balkon yang berada di atas sungai dan pintu ke luar unit menuju balkon. Outcomes yang diharapkan berupa guidelines tentang penataan ruang per unit beserta balkonnya. Tahap 2; Memberikan contoh unit yang sehat baik dari segi pemilihan materialnya, sirkulasi udara, pemilihan terhadap warna. Tahap 3; Memberikan contoh balkon yang kokoh, indah, enak dipandang, serta pengecatan warna warni. Sekarang ini baru dilakukan pengabdian tahap 1.
\end{abstract}

Kata kunci: Guidelines; Permukiman deret; Tepian sungai

\section{PENDAHULUAN}

Latar Belakang

Perkembangan sebuah kota tidak dapat dilepaskan dari keterkaitan antara sistem dengan siklus kehidupan, yang terdiri dari kepadatan penduduk yang tinggi dan diwarnai dengan strata sosial 
ekonomi yang heterogen (Bintarto,1989:36). Perkembangan suatu kota tidak hanya yang terlihat secara fisik tetapi juga non fisiknya, tak kalah penting kondisi topografi juga mempengaruhi perkembangan suatu kota.

Jakarta merupakan salah satu kota dengan tingkat pertumbuhan ekonomi yang cukup tinggi. Lebih dari $70 \%$ uang negara beredar di Jakarta. Perekonomian Jakarta yang utama adalah sektor perdagangan, jasa, properti, industri kreatif, dan keuangan. Dilihat dari tata bangunannya, Jakarta Barat merupakan salah satu bagian dari Jakarta yang relative masih mempunyai bangunan yang tertata dengan baik, tetapi masih ada beberapa bagian wilayah yang kelihatan kumuh, antara lain perkampungan Luar Batang, kolong jembatan layang yang berada di dekat Pasar Ikan, Jalan Kakap, serta tepian sungai Duri yang berada di seberang Roxy Mas.

\section{Analisis situasi}

Sungai Duri yang berada di depan Roxy Mas sebagai berikut; kawasan tepian sungai yang dapat menjadi icon kota Jakarta Barat, faktanya wilayah tersebut kumuh tak beraturan. Rumah tumbuh di tepian sungai menjamur. Dampak yang terjadi adalah air sungai di belakang deretan rumah tersebut, tidak sehat, hitam, berbau, penuh sampah, dan menjadi mck bagi penghuni rumah deret.

\section{Tujuan}

Pengabdian masyarakat ini bertujuan untuk memanfaatkan permukiman pinggiran sungai yang terlanjur ada untuk yang terkesan kumuh dan tidak sehat untuk dijadikan deretan permukiman yang sehat dan menarik. Dapat dijadikan salah satu daya tarik wilayah Jakarta Barat.

\section{Permasalahan}

Permasalahan yang muncul adalah banyak wilayah tepian sungai di Indonesia khususnya pemanfaatan ruang di sepanjang tepi sungai sangat memprihatinkan; adanya permukiman yang padat yang tumbuh sampai menjorok ke badan sungai, adanya penggundulan tanaman pelindung bibir sungai, pengerukan pasir, hingga pembuangan limbah baik limbah padat maupun cair ataupun limbah yang berasal dari industri maupun rumah tangga. Hal-hal tersebut secara keseluruhan akan membawa pengaruh buruk bagi kawasan tepian sungai itu sendiri maupun air sungainya. Dari sisi keindahan kota kampung deret semacam itu sangat mengganggu.

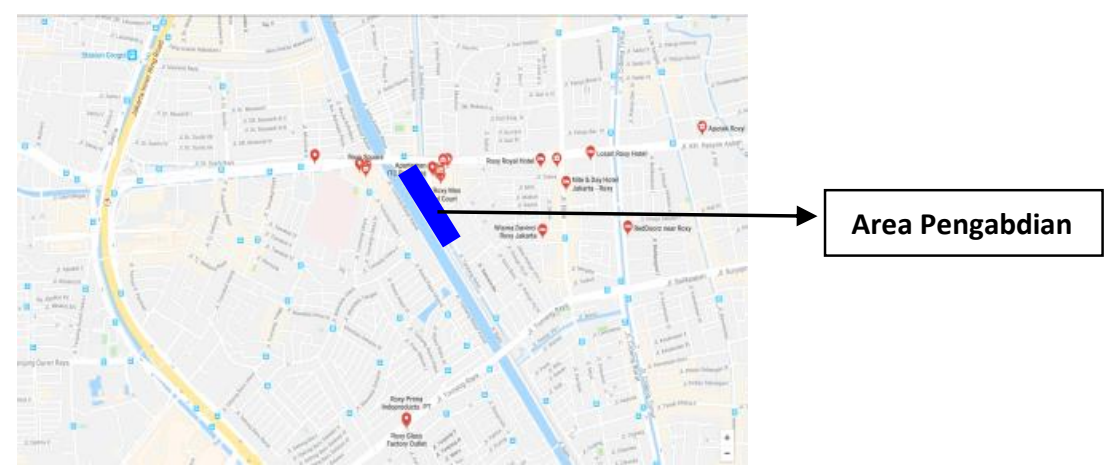

Gambar 1. Tata Letak Lahan untuk Pengabdian Masyarakat Tepian Sungai Duri Seberang Roxy Mas

(Sumber: Google 2019) 

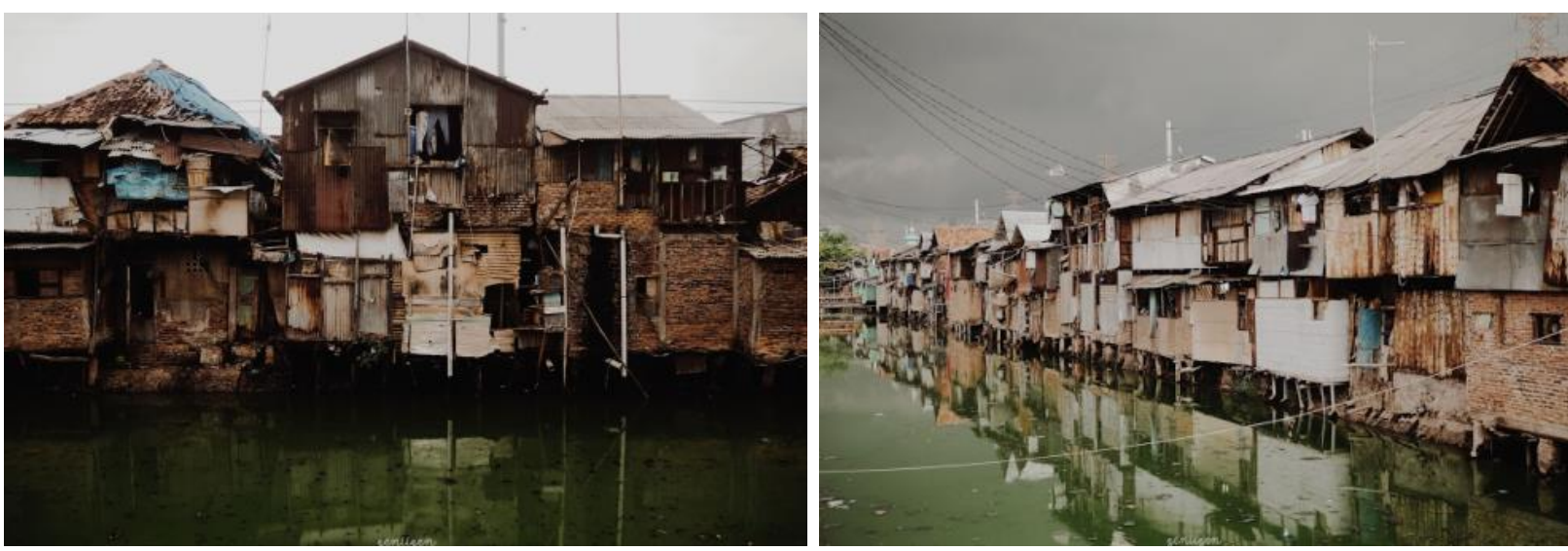

Gambar 2. Situasi Lokasi Lahan untuk Pengabdian Masyarakat Tepian Sungai Duri Seberang Roxy Mas

(Sumber: Data Pribadi, 2019)

\section{METODE PELAKSANAAN PKM}

Pengabdian ini merupakan pengabdian yang 1 (pertama) dari 3 (tiga) pengabdian yang akan dilakukan. Pada tahap 1 (pertama) peneliti lebih focus kepada masyarakat sebagai penghuni rumah deret di tepian sungai Duri di sebelah Roxy Mas. Metoda yang dipakai kualitatif dengan cara pendekatan kepada masyarakat penghuni dengan memakai teori Strategy Grounded Theory Research, dengan cara wawancara mendalam dengan metoda Focus Group Discussion (FGD) untuk mendapatkan data social dan kulturnya (Anselm Strauss: 1990). Selain itu juga mengamati perilaku masyarakat penghuni dalam menjalankan kehidupan sehari-hari. Bagaimana mereka menyikapi ruang yang berkaitan langsung dengan sungai yang berada di bawah dan belakang rumahnya. Bagaimana mereka memandang kebersihan rumah dan lingkungannya. Bagaimana mereka mengartikan keindahan dimana rumah deret mereka merupakan bagian dari kota besar. Pengamatan ini dibantu dengan kuesioner sehingga data dapat di kros-cek kan untuk mendapatkan data yang akurat.

Tahapan yang dilakukan; 1. Mengadakan FGD dengan harapan dapat memahami keinginan dari para penghuni unit serta data-data kepemilikan, 2. Mendokumentasikan serta mengadakan pengukuran unit ruang. 3. Pengecekan keberadaan balkon yang berada di atas sungai dan pintu ke luar unit menuju balkon, 4. Penggambaran data lapangan, 5. Membuat Analisis, 6. Membuat guidelines dan sketsa perkiraan bentuk permukiman setelah diadakan pengabdian masyarakat.

Outcomes yang diharapkan berupa guiden lines tentang penataan ruang per unit beserta balkonnya. Tahap 2; Memberikan contoh unit yang sehat baik dari segi pemilihan materialnya, sirkulasi udara, pemilihan terhadap warna. Tahap 3; Memberikan contoh balkon yang kokoh, indah, enak dipandang, serta pengecatan warna warni.

\section{HASIL DAN PEMBAHASAN}

Penghuni yang terdata di Kalurahan Cideng Kacamatan Gambir, terdiri 10 RT, 750 kk dan 330 rumah Dengan tercatatnya secara resmi penduduk tersebut di Kalurahan artinya mereka penduduk legal di DKI. Sedangkan tanah yang ditempati merupakan bantaran tepian singai yang tidak legal untuk bangunan. Masalah menjadi sangat kompleks. Hal tersebut menarik untuk diteliti dalam hal; bagaimana menyelesaikan masalah permukiman tersebut dari sesuatu yang terlihat kumuh dari sisi 
pandang kota besar menjadi ssesuatu yang menarik dan bermanfaat untuk kota besar tersebut. Manfaat yang ingin dicapai; menjadikan rumah tumbuh sepanjang sungai tersebut dapat diselaraskan dengan lingkungan fisik alamiah sesuai dengan kebutuhan manusia akan ruang aktifitas sebagai satu kesatuan yang tidak terpisahkan dalam suatu bentuk kawasan perkotaan. Dengan memandang kebutuhan akan ruang gerak manusia dan keindahan.

Apabila dilihat dari lokasinya kawasan ini termasuk wilayah bisnis dimana berdiri pusat perbelanjaan Roxy Mas dan perkantoran serta pertokoan di sepanjang jalan Kyai Hasyim Ashari. Kawasan ini cukup menarik karena dilalui oleh sungai Duri, yang sebenarnya berpotensi besar untuk dapat dijadikan icon kota seperti di Malaka, Brunai, dan kota-kota lainnya yang mempunyai sungai di tengah kotanya. Pada tanggal 6 Agustus 2019 jam 9-12 diadakan FGD di Balai Warga RW 7 seperti pada Gambar 4 dan Gambar 5. Hasil FGD dapat dilihat pada Tabel 1.

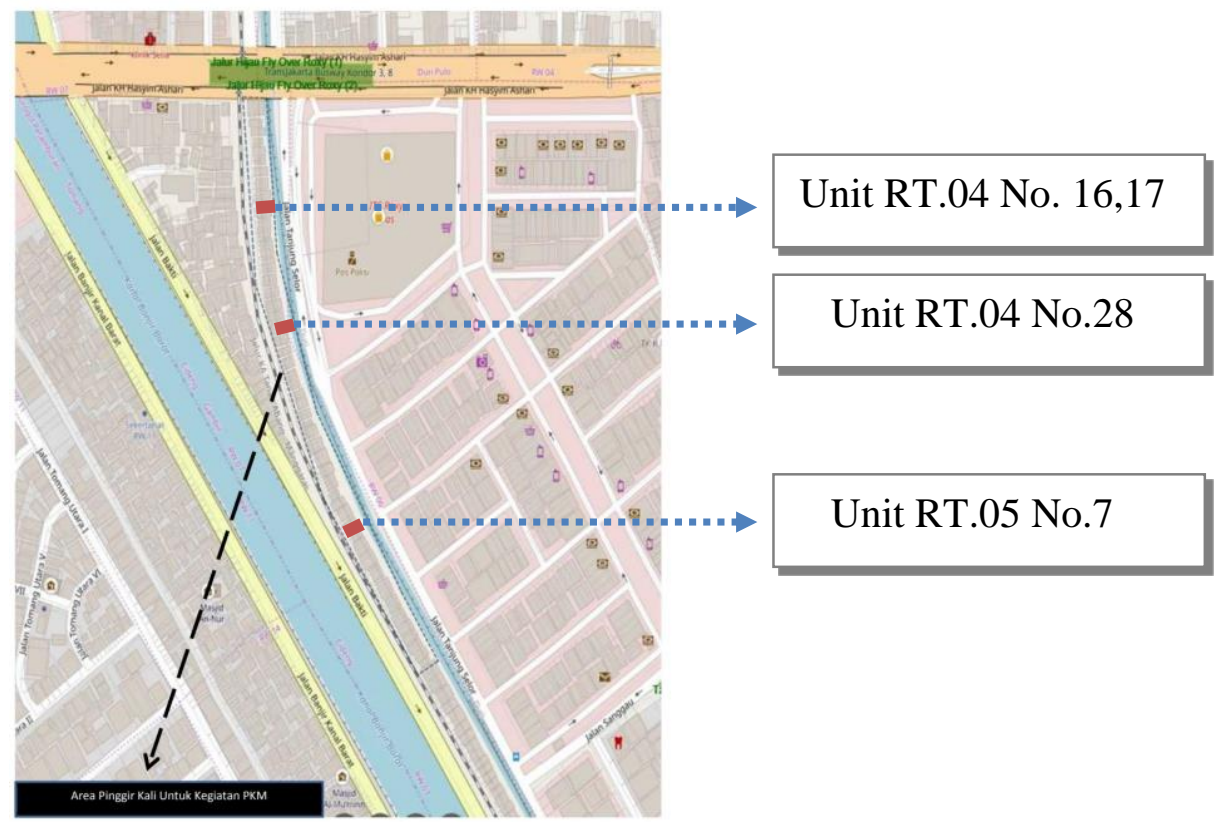

Gambar 4. FGD dengan mengambil sampel acak (Sumber: Data Pribadi, 2019)
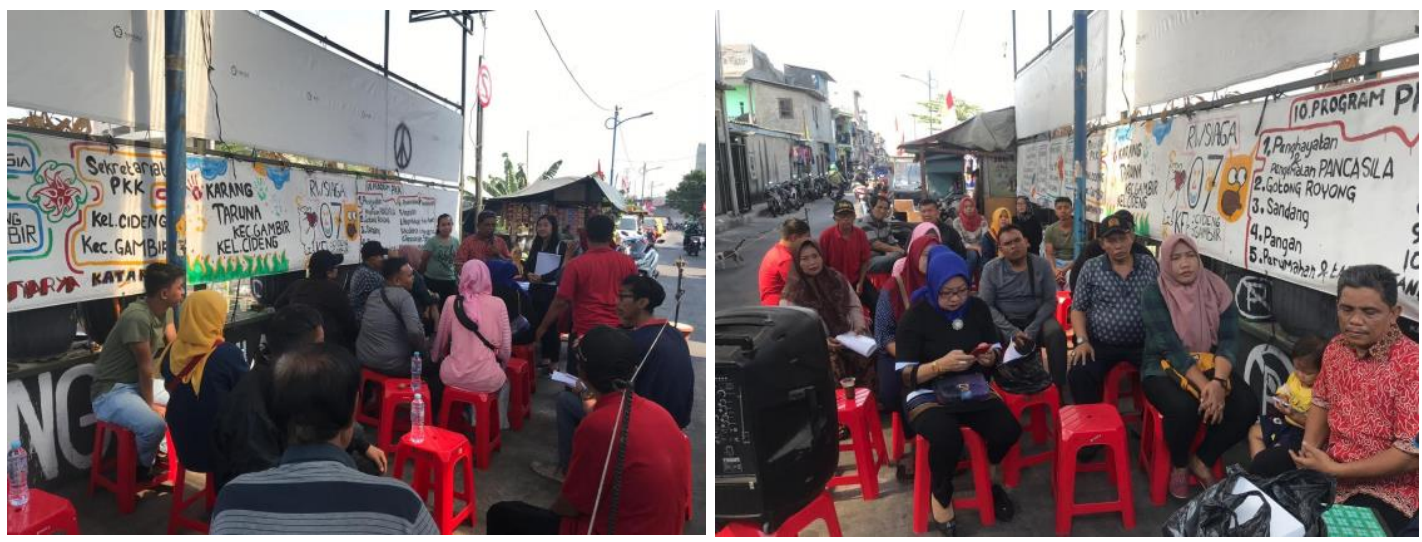

Gambar 5. Dokumentasi Kegiatan FGD

(Sumber: Data Pribadi, 2019) 
Tabel 1. Hasil FGD

\begin{tabular}{|c|c|c|c|c|c|c|c|c|c|c|}
\hline No & Nama & Alamat & $\begin{array}{l}\text { Status } \\
\text { Rumah }\end{array}$ & $\begin{array}{l}\text { Luas } \\
\text { Unit } \\
(m)\end{array}$ & $\begin{array}{c}\text { Juml } \\
\text { ah } \\
\text { Peng } \\
\text { huni } \\
\end{array}$ & $\begin{array}{c}\mathrm{MC} \\
\mathrm{K}\end{array}$ & $\begin{array}{c}\text { Saluran } \\
\text { Pembua } \\
\text { ngan }\end{array}$ & $\begin{array}{c}\text { Pem } \\
\text { buangan } \\
\text { Sampah }\end{array}$ & $\begin{array}{c}\text { Sikap } \\
\text { Thd } \\
\text { Lingku } \\
\text { ngan } \\
\end{array}$ & $\begin{array}{c}\text { Kesediaa } \\
\text { n Unt } \\
\text { Perbaika } \\
\text { n } \\
\end{array}$ \\
\hline 1 & Suhari & RW 7/RT 4-14 & Hak Milik & $2,6 \times 8$ & 8 & Ada & $\begin{array}{l}\text { Langsun } \\
\mathrm{g} \text { ke } \\
\text { sungai }\end{array}$ & $\begin{array}{l}\text { Buang ke } \\
\text { pasar }\end{array}$ & $\begin{array}{l}\text { Sangat } \\
\text { peduli }\end{array}$ & Bersedia \\
\hline 2 & Sukiman & RW7/RT 6-22A & Hak Milik & $1,8 \times 3$ & 4 & $\begin{array}{l}\text { Tida } \\
\mathrm{k}\end{array}$ & Idem & $\begin{array}{l}\text { Petugas } \\
\text { sampah }\end{array}$ & Idem & Idem \\
\hline 3 & Sri Sukarni & $\begin{array}{l}\text { RW 7/RT 4-45- } \\
46\end{array}$ & Hak Milik & $5,4 \times 8$ & 30 & Ada & Idem & $\begin{array}{l}\text { Langsun } \\
\text { g ke } \\
\text { sungai }\end{array}$ & Idem & Idem \\
\hline 4 & Sinta Maryana & RW 7/RT 8-19 & Hak Milik & $5,4 \times 8$ & 4 & Ada & Idem & $\begin{array}{l}\text { Ada } \\
\text { petugas } \\
\text { sampah }\end{array}$ & Idem & Idem \\
\hline 5 & Sabarni & $\begin{array}{l}\text { RW7/RT4-16- } \\
17 \text { dan 4A }\end{array}$ & Hak Milik & $\begin{array}{l}5.4 \times 8 \\
2.6 \times 8\end{array}$ & 7 & Ada & Idem & $\begin{array}{l}\text { Dibuang } \\
\text { ke pasar }\end{array}$ & Idem & Idem \\
\hline 6 & Sumantri & RW 7/RT7-35 & Hak Milik & $2,6 \mathrm{x} 8$ & 5 & Ada & Idem & $\begin{array}{l}\text { Petugas } \\
\text { sampah }\end{array}$ & Idem & Idem \\
\hline 7 & Teguh Prayitno & RW 7/RT $7-12$ & Hak Milik & $2,6 \times 8$ & 3 & Ada & Idem & $\begin{array}{l}\text { Petugas } \\
\text { sampah }\end{array}$ & Idem & Idem \\
\hline 8 & Suwarni & RW 7/Rt8-21 & Hak Milik & $3.5 \times 8$ & 5 & Ada & Idem & $\begin{array}{l}\text { Petugas } \\
\text { sampah }\end{array}$ & Idem & Idem \\
\hline 9 & Hartati & RW 7/RT7-24 & Hak Milik & $2,6 \times 8$ & 8 & Ada & Idem & $\begin{array}{l}\text { Petugas } \\
\text { sampah }\end{array}$ & Idem & Idem \\
\hline 10 & Yohar Awaludin & RW7/RT9-28 & Hak Milik & $1,8 \mathrm{x} 8$ & 2 & Ada & Idem & $\begin{array}{l}\text { Petugas } \\
\text { sampah }\end{array}$ & Idem & Idem \\
\hline 11 & Soni & RW7/RT 8-10 & Sewa & $2,6 \times 8$ & 7 & Ada & Idem & $\begin{array}{l}\text { Petugas } \\
\text { sampah }\end{array}$ & Idem & Idem \\
\hline 12 & $\begin{array}{l}\text { Munawar } \\
\text { (Awang) }\end{array}$ & RW 7/RT 9-4 & Hak Milik & $2,6 \times 8$ & 5 & Ada & Idem & $\begin{array}{l}\text { Petugas } \\
\text { sampah }\end{array}$ & Idem & Idem \\
\hline 13 & Sri Sutanti & RW 7/RT 5-26 & Hak Milik & $3,5 \times 8$ & 3 & Ada & Idem & $\begin{array}{l}\text { Petugas } \\
\text { sampah }\end{array}$ & Idem & Idem \\
\hline 14 & Junarto & RW 7/RT 5-8 & Hak Milik & $5,4 \times 8$ & 6 & Ada & Idem & $\begin{array}{l}\text { Petugas } \\
\text { sampah }\end{array}$ & Idem & Idem \\
\hline 15 & Eko Pambudi & RW7/RT4-48 & Hak Milik & $3,5 \times 8$ & 2 & Ada & Idem & $\begin{array}{l}\text { Petugas } \\
\text { sampah }\end{array}$ & Idem & Idem \\
\hline 16 & Sukiyono & RW7/RT5-2 & Hak Milik & $5,4 \times 8$ & 4 & Ada & Idem & $\begin{array}{l}\text { Petugas } \\
\text { sampah }\end{array}$ & Idem & Idem \\
\hline $\begin{array}{l}\text { Reka } \\
\mathrm{p}\end{array}$ & & & Hak Milk & $\begin{array}{l}\text { Ada } 4 \\
\text { prototipe } \\
\text { ukuran: } \\
5,4 \times 8 \\
2,6 \times 8 \\
1,8 \times 8\end{array}$ & & & & & & \\
\hline
\end{tabular}

Dari hasil rekapitulasi didapat data; kebanyakan status unit adalah hak milik, dengan ukuran unit $5,4 \times 8,6 \times 8,1,8 \times 8 \mathrm{~m}$ rata penghuni unit 5 orang. Semua mempunyai MCK yang langsung dibuang ke sungai. Ada pengambilan sampah tetapi ada beberapa yang dibuang ke sungai atau dibuang ke pasar. Mereka sepakat kalau ada perbaikan lingkungan. Untuk mendapatkan data akurat tentang situasi lingkungan dan material yang digunakan maka diadakan pengamatan lapangan dengan hasil seperti pada Gambar 6.

Data yang didapat di lapangan belum memperhatikan keselamatan, sirkulasi udara, kebersihan, kesehatan, kerapihan, serta keindahannya. Material bangunan yang dipakai merupakan material bekas yang sebenarnya sudah tidak layak pakai, hal ini dapat membahayakan terhadap keselamatan dan kesehatan penghuni. Ukuran unit dan kapasitas penghuni juga belum memenuhi standar hunian. MCK langsung ke sungai, berpotensi menimbulkan banyak penyakit. Sketsa unit setelah diadakan pengabdian masyarakat dapat dilihat pada Gambar 7. 


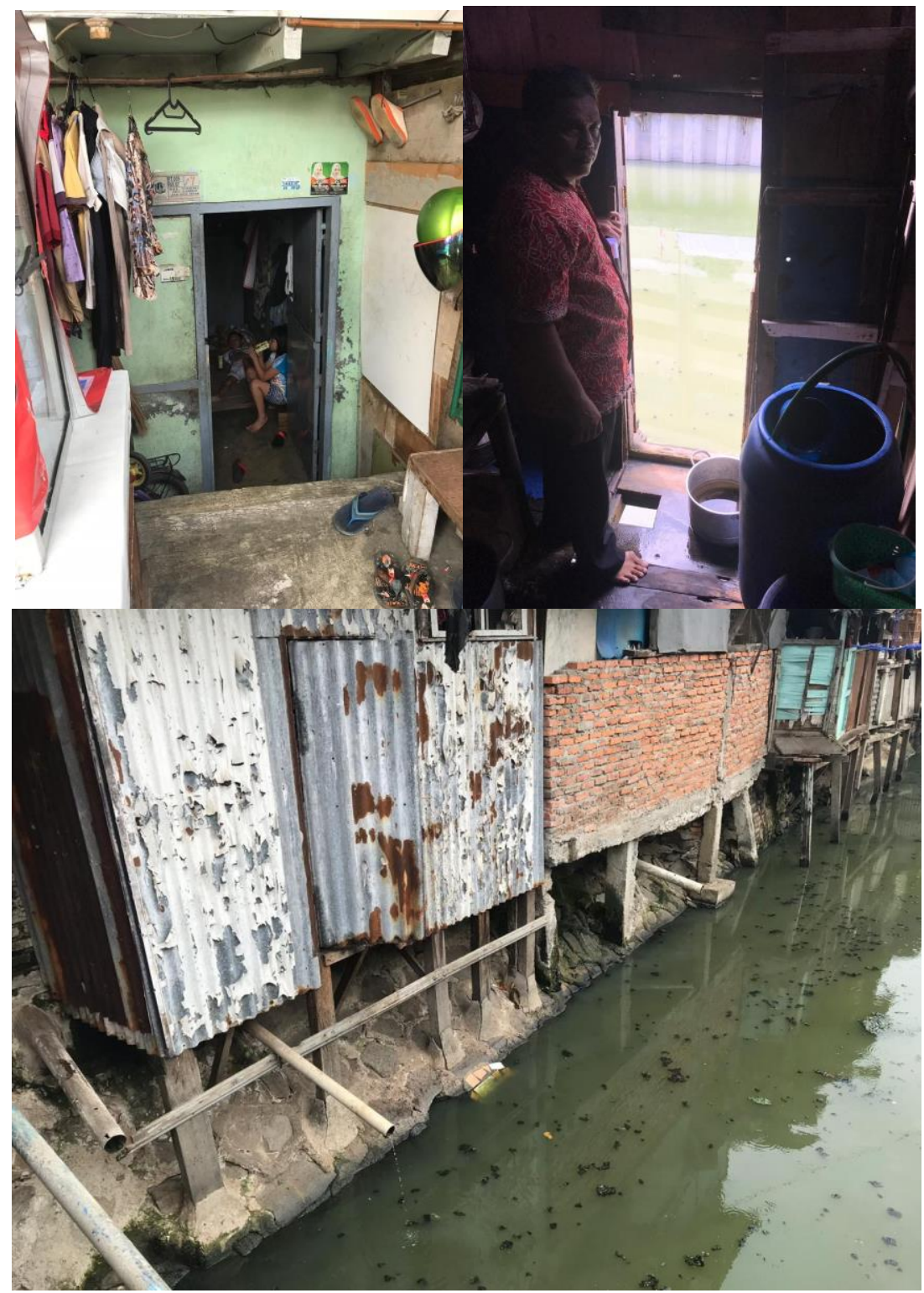

Gambar 6. Dokumentasi Kondisi Lingkungan (Sumber: Data Pribadi, 2019)

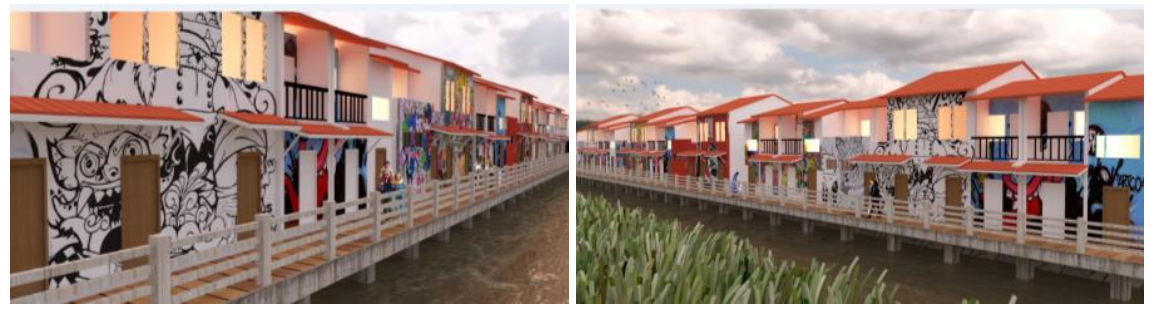

Gambar 7. Sketsa Unit Setelah diadakan Pengabdian Masyarakat (Sumber: Data Pribadi, 2019)

\section{KESIMPULAN}

Dari hasil pengabdian tahap pertama ini didapat kesimpulan bahwa diperlukan guiden lines tentang penataan kawan tepian sungai antara lain: 
1. Perlu adanya septictank bersama yang mengapung di sungai. Sehingga memudahksn petugas membersihkan septictank secara berkala

2. Perlu adanya bak sampah besar yang secara berkala diambil petugas

3. Teras depan yang berupa lorong bersama bisa dirapikan dan difungsikan sebagai ruang duduk serta ruang untuk ber interaksi sosial

4. Pembagian ruang dalam unit perlu ada pemisahan antara ruang privat dan non privat

5. Balkon yang berada di atas tepian sungai perlu ditata khusus sehingga dapat dijadikan icon kota yang pada pengabdian berikutnya bisa diberikan pengarahan tentang estetika warna warni cat yang dipilih

\section{REFERENSI}

https://kampungderetjoharbaru.wordpress.com/pentingnya-pembangunan-kampung-deretvertikal/, diunduh 8 Maret 2019.

http://weburbanist.com/2014/12/11/vertical-city-farming-undulating-mixed-use-urbancommunity/, diunduh 8 Maret 2019.

http://www.jakartaverticalkampung.org/, diunduh 8 Maret 2019.

http://www.kompasiana.com/alifianorezkaadi/infrastruktur-dan-transportasi-sebagai-pendukungkonsep-kampung-vertikal_557b88d1c523bde9328df703, diunduh 8 Maret 2019.

http://www.kompasiana.com/alifianorezkaadi/mencorat-coret-lingkungan-sekitar-menjadi-lebihekologis_54f9038fa33311a13d8b497e, diunduh 8 Maret 2019.

http://www.kompasiana.com/alifianorezkaadi/pengembangan-mixed-use-dalam-sistem-todkonsep-pengembangan-kota-masa-depan_555317f2b67e619b0c13099b, diunduh 8 Maret 2019.

http://www.kompasiana.com/alifianorezkaadi/rusunami-solusi-permukiman-bantaransungai_54f9020da3331123098b4dd2, diunduh 8 Maret 2019.

http://www.kompasiana.com/alifianorezkaadi/sesekali-berimajinasi-tentang-kota-masadepan_552ca8716ea834c8338b4588, diunduh 8 Maret 2019.

http://www.mccarter.com/Mixed-Use-Developments--The-Coming-of-Age-of-VerticalDivisions-08-01-2007/, diunduh 8 Maret 2019.

http://www.mondaq.com/unitedstates/x/298074/agriculture+land+law/Establishing+Separate+ Ownership+in+a+Vertical+Mixed+Use+Project, diunduh 8 Maret 2019.

Noor, Ikhsan Fitrian, (2005), Arahan Penataan Kawasan Tepian Sungai Kandilo Kota Tanah Grogot Kabupaten Pasir Propinsi Kalimantan Timur, Jurusan Perencanaan Wilayah Dan Kota, Fakultas Teknik Universitas Diponegoro, Semarang.

Prasetya, L. Edhi, (2008) Penataan Kawasan Bantaran Sungai Martapura Banjarmasin Sebagai Ruang Terbuka Rekreatif, Seminar Nasional Peran Arsitektur Perkotaan dalam Mewujudkan Kota Tropis, 6 Agustus 2008, Gedung Prof Soedarto, SH Kampus UNDIP Tembalang Semarang.

Rahmani, Hudan et al., (2017), Studi Penataan Lahan Permukiman Di Tepi Sungai Dengan Metode Buffer Zone Untuk Kelestarian Lingkungan Di Kelurahan Alalak, Kota Banjarmasin, Study on the Arrangement of the River Bank Settlement Land with Bufferzonal Method to Environment Conservation in Village Alalak of Banjarmasin City, Prosiding Seminar Nasional Lahan Basah, Tahun 2016 Jilid 3: 998-1005 ISBN 978-6026483-40-9, Lembaga Penelitian dan Pengabdian kepada Masyarakat, Universitas Lambung Mangkurat, Fakultas Teknik Prodi Teknik Sipil Universitas Islam Kalimantan MAAB.

Setianingsih, Sri dan Ersina, Sriany, (2015), Penataan Tepian Sungai Cenranae Dengan Pendekatan Ekologis Di Kota Sengkang, Jurnal National Academic Journal of Architecture, Jurusan Arsitektur Fakultas Sains \& Teknologi UIN-Alauddin Makassar. 